\title{
Brončano doba i recikliranje brončanih predmeta
}

\author{
Snježana Karavanić
}

DOI: $10.17234 / 9789531757232-06$

\section{Uvod}

Brončano doba jedno je od najznačajnijih tzv. metalnih razdoblja u ljudskoj prošlosti, a njegova važnost je čovjekovo otkriće, odnosno sposobnost da stvori novi materijal koji je nepovratno promijenio ljudsku prošlost, broncu. Bronca je umjetno stvorena slitina sačinjena od $90 \%$ bakra i 10\% kositra, a koristila se za lijevanje različitih predmeta (alat, nakit, oružje i sl.). Osim lijevanja bronca se obrađivala i kovanjem, a tzv. hladno kovanje pozitivno utječe na tvrdoću materijala. Mnoga složena tehnološka znanja i prakse ovisile su i o izvorima sirovine, njihovoj dostupnosti te tada već razvijenim trgovačkim mrežama. Takva su zbivanja dio složenih društvenih promjena na prostoru Europe. U radu će se pokušati prikazati u kojoj su mjeri povezana izvorišta sirovina, proizvodnja predmeta od bronce, deponiranje bronce i lomljenih brončanih predmeta te mogu li se brojne ostave brončanih predmeta tumačiti kao reciklažni otpad.

\section{O brončanom dobu i bronci}

Pojam „brončano doba“ dio je trodijelne sheme koju je uspostavio Christian Jürgensen Thomsen 1836. godine (Kristiansen 1998: 24) podijelivši najstariju povijest čovječanstva na kameno, bakreno i brončano doba. Nakon toga uslijedile su klasifikacije i prve kronologije brončanodobnog materijala. ${ }^{1}$ On je svoj sustav zasnivao na brojnim ostavama brončanih predmeta jer grobne i druge cjeline nisu u to vrijeme postojale. Tzv. Reineckeovu podjelu brončanoga doba (relativna kronologija se zasniva na stupnjevima), koja se zasniva na tipološkoj klasifikaciji i periodizaciji brončanodobnog materijala na području Bavarske prihvatili su i naši autori koji se bave brončanim dobom.

Kao što samo ime kaže, brončano doba dobilo je ime prema osnovnom materijalu od kojega su se izrađivali brojni predmeti (oruđe, nakit i nošnja, oružje). Bronca je legura ili slitina bakra koja nastaje tako da se bakru dodaje kositar u idealnom omjeru 9:1. U ranijem razdoblju za izradu oruđa i oružja koristio se vrlo mekan metal, bakar, stoga je potreba za povećanjem tvrdoće materijala/oruđa dovela do razvoja novih znanja i tehnologije. Već u kasnom eneolitiku postoji pojam arsenske bronce, slitine bakra i arsena s udjelom arsena od 30\%, a osim arsena, često se nalazi i antimon. Ovi elementi poboljšavaju livkost i tvrdoću bakra, pa su stari ljevači nastojali zadržati ove elemente koji se inače izdvajaju već pri $700^{\circ} \mathrm{C}$. U to vrijeme se već može govoriti o legurama ili slitinama. Važno je napomenuti da je proces dodavanja arsena zahtijevao veliku stručnost jer je arsen dosta otrovan. ${ }^{2}$

\footnotetext{
1 Za sjevernu Europu to je Monteliusova podjela, dok je za srednju Europu presudna bila ona Reineckeova koja se temeljila na tipološkoj klasifikaciji i periodizaciji brončanodobnog materijala na području južne Bavarske.

${ }^{2}$ U starogrčkoj mitologiji šepavog boga Hefesta smatra se zaštitnikom ljevača koji su se nakon mnogo godina rada kretali kao pijani ili šepavi (Durman 2004).
} 
Tek nakon arsenske bronce, dolazi period tzv. kositrene bronce, slitine bakra i kositra koja je omogućila proizvodnju tvrđih i kvalitetnijih predmeta. Talište bronce je na oko $1200^{\circ} \mathrm{C}$. Kronološki gledano, u formativnoj fazi ranoga brončanog doba u periodu 2300./2200. pr. Kr. pojavljuje se i dalje arsenska bronca, ali najkarakterističniji su bakreni predmeti s velikim udjelom srebra i antimona (Fahlerz). Neki autori (Fischl et al. 2015) navode da postoje nalazi predmeta s udjelom kositra većim od 1,00\% prije nego što su se prave kositrene bronce počele pojavljivati.

U periodu arheološkoga ranog brončanog doba kositar se javlja u malom postotku (1-4\%) i to u predmetima koji sadrže i znatne količine arsena. Zato neki stručnjaci smatraju da naziv rano brončano doba nije prikladan za period u kojem se kositar javlja u tako malom postotku (Tylecote 1976: 15). Većina arsenskih bronci rezultat je prerade bakrenih rudača koje su uz ostale primjese sadržavale i kositar.

Sljedeći korak bilo je dodavanje kositra, bilo kao oksida ili metala, arsenskom bakru. Kositrene bronce su široko rasprostranjene tek u periodu od 2100. do 1800. pr. Kr., odnosno u razdoblju prijelaza iz ranoga u srednje brončano doba. U srednjem brončanom dobu lokalne radionice koje su dotad kopirale uvezene predmete počinju razvijati svoj vlastiti repertoar (Fischl et al. 2015: 515). Slitina bronce mogla je nastati na nekoliko načina: zajedničkim taljenjem metalnog bakra i kositra, dodavanjem minerala kasiterita rastaljenom bakru ili topljenjem prirodne bakreno-kositrene rudače ili topljenjem smjese bakrene rudače s kasiteritom. Budući da se kositar tali već na $232^{\circ} \mathrm{C}$, on smanjuje točku taljenja bakra s $1084^{\circ} \mathrm{C}$ na $950^{\circ} \mathrm{C}$. Prelazak na broncu ne znači prestanak upotrebe čistog bakra i legure bakra i arsena. Tijekom srednjega brončanog doba smanjuje se postotak arsena što može biti posljedica promjene tehnike prerade rudače (povećana oksidacija) ili promjene sastava rudače s dubinom rudnog ležišta (Tylecote 1976:15).

Kasno brončano doba u periodu od 1300. do 800. godine pr. Kr. vrijeme je kada umijeće lijevanja doseže svoj uspon. To je vrijeme kada se javlja i jedna inovacija, naime, bronci se dodaje i olovo koje povećava njezinu livkost (Tylecote 1976).

Vrijeme kasnoga brončanog doba za neke autore je vrijeme revolucije (Harding 1998: 309) u mnogim aspektima života pa tako i u proizvodnji metala. To se očituje u povećanoj serijskoj proizvodnji različitih tipova predmeta. Nalazi iz naselja, nekropola i ostava svjedoče o razvijenoj distribuciji sirovina i o trgovini gotovim predmetima. Ovome prethode ekstenzivna iskorištavanja rudnih ležišta u Europi. Brojni su radovi koji donose značajne podatke o rudnim ležištima u srednjoj Europi i Karpatskoj kotlini (Tylecote 1976; Pernicka 1993; Craddock 1995; Krause 2003). Ležišta bakra nalazila su se na različitim dijelovima Balkana (Bugarska, Srbija, Albanija), u Karpatima (Transilvanija, Slovačka), u jugoistočnim Alpama (Austrija), u srednjoj Europi (Harz i Erzgebirge), u zapadnoj Europi (Francuska, Španjolska, Britanija i Irska). Rezultati istraživanja nam daju podatke o postojanju ležišta rudača, rudnika, mjesta na kojima se rudača prerađivala. Na tim lokalitetima pronađeni su ostaci peći kao i predmeti koji su se upotrebljavali u metalurškoj i ljevačkoj djelatnosti.

\section{Ležišta sirovina}

Za naše prostore od velike su važnosti ležišta bakra i rudnici u istočnim Alpama. Ta ležišta se rasprostiru na oko $450 \mathrm{~km}$ dužine na prostoru od Unterinntala preko Salzachtala i Pongaua s područjem Mitterberga, sve o Paltentala i «Eisenerz» Alpa u Štajerskoj (Krause 2003: 36). Drugo rudonosno područje, koje također može biti dosta značajno za usporedbu, jest područje Slovačke. To je područje, zajedno s njemačko-saskim Rudogorjem i Alpama jedno od najznačajnijih rudarskih područja u srednjoj Europi. Važnost toga područja je istaknuo i V. G. Childe koji je rudama bogate Karpate označio kao glavnu osnovu za razvoj brončanodobnih kultura u 
Karpatskoj kotlini (Krause 2003: 41). Za istraživanje rane metalurgije u sjevernoj Mađarskoj i Slovačkoj bile su presudne brojne analize koje su 60-ih godina proveli Schubert, Sangmeister, Junghans i Schröder, a u isto vrijeme Colin Renfrew je istaknuo i područje Slovačke kao jedno od značajnih područja za nastanak i razvoj samostalne metalurgije u jugoistočnoj Europi (Schalk 2002: 266). U Slovačkoj postoji nekoliko nalazišta na kojima se iskorištavao bakar u prapovijesti (Špania Dolina, Španie Pole, Slovinky i Stará Bistrica), no postoje indicije da se kositar u formi kasiterita dobivao iz manjih aluvijalnih ležišta (Zips-Gemer Rudogorje, Niske Tatre i Považský Inovec ) (Furmánek \& Vladar 2002: 259).

Među ostala područja bogata bakrom i kositrom ubrajaju se ona u južnim Alpama i na Balkanu (Krause 2003: 42). Najpoznatije je ono u Rudnoj Glavi u Srbiji i Ai Bunar u južnoj Bugarskoj.

U ranom brončanom dobu pretpostavlja se iskorištavanje ležišta kositra u Srbiji (McGeehanLiritzis \& Taylor 1987; Durman 1997). Ležišta su se nalazila na području planina Cer, Bukulja i Srebrenica. Ove žile su tercijarni depoziti (McGeehan-Liritzis \& Taylor 1987: 289). Ipak, najznačajnija ležišta su aluvijalnog kasiterita koja su bila i najprihvatljivija za ranobrončanodobne populacije, a bilo ga je izgleda dovoljno za distribuciju u druge krajeve pa tako i u Egeju (McGeehan-Liritzis \& Taylor 1987: 290). Na ova se istraživanja nadovezuje i ono, koje pretpostavlja, na osnovi geoloških sličnosti planinskih masiva, ležišta kositra i u sjevernoj Bosni (Durman 1997). Iako ovo istraživanje nije temeljeno na terenskom istraživanju, vrlo je važno za promatranje bogate brončane industrije kulture polja sa žarama u sjevernoj Hrvatskoj i sjevernoj Bosni.

Međutim, najmanje podataka imamo o početnim fazama metalurškog procesa koje obuhvaćaju ležišta rudača, preradu sirovine i njezinu distribuciju do radioničkih središta kulture polja sa žarama. Nešto više podataka o toj djelatnosti dala su nam istraživanja u Tridentu, južnom i sjevernom Tirolu (Trampuž-Orel 1999: 413). Na prostoru Slovenije istraživanja su pokazala da je struktura bakrenih slitina u slovenskim kasnobrončanodobnim ostavama ovisila o tehnološkom znanju drevnih majstora kao i o različitim izvorima bakrene sirovine (Trampuž-Orel 1999: 415).

Za razdoblje 12. i 11. st. pr. Kr. (Ha A stupanj) karakteristična je pojava različitih tipova bakrenih slitina s kositrom što znači da su majstori pažljivo određivali slitinu prema tipu i funkciji gotovog proizvoda. Tako se najmanje kositra dodavalo za izradu srpova, a slitine s više kositra bile su namijenjene za izradu oružja (mačevi, koplja) i oruđa (sjekire) (Trampuž-Orel 1999: 415). Spomenuta istraživanja otkrila su značajnu promjenu u tehnologiji i upotrebi sirovina tijekom prijelaza u 1. tis. pr. Kr. (Ha A2/B1) (Trampuž-Orel 1999: 417).

Tijekom 1. tis. karakteristično je dodavanje olova bakrenim i brončanim slitinama pri čemu olovo nikada nije prisutno kao čisti metal nego kao drugi sastojak slitine bakra ili treći sastojak slitine bakra i kositra. Pojavljuje se u većoj mjeri u predmetima i ingotima. Sada se pojavljuje novi tip sirovine u obliku ingota (lijevanih u kalupima) (Trampuž-Orel 1999: 418). Za razliku od jednostavnih plano-convex ingota, lijevani ingoti su bili indikator novog tipa metala koji se proizvodio. Bakar koji se koristio u ovom periodu imao je više nečistoća, osobito antimona pa se može pripisati sulfidnim rudačama, prije svega tipu Fahlerz.

S teritorija današnje Republike Hrvatske poznati su rezultati triju analiza strukture metala iz ostava bronačnih premeta: Miljana (Smodič 1956), Pustakovec (Riederer 1999) i Dežmanov prolaz (Glogović 2000). Ostava iz Pustakovca datirana je u fazu II kulture polja sa žarama (Hänsel 1999; Glogović \& Miko 2000), a metodom atomske apsorpcije napravljena je analiza tzv. brončanih „pogača“, koje su bile sirovina koja je u toj formi stizala u naselja u kojima se odvijala ljevačka djelatnost. Istraživanje je pokazalo da se niti kod jednog od sedam uzoraka ne radi o čistoj bakrenoj rudači, nego o istopljenom metalu s različitim elementima u tragovima. Iz ostave u Dežmanovom prolazu analizirana su dva grumena ili „pogače“ (Glogović \& Miko 2000: sl. 2). Autori rezultate analiza dovode u vezu sa skupinom predmeta s područja Slovenije (Tram- 
puž-Orel 1996: 204) te spominju i značajan postotak srebra što je oznaka alpskih ležišta bakra (Glogović \& Miko 2000: 91).

Prostor južne Panonije pa tako i lokaliteti u Hrvatskoj možda bi mogli pokazivati nešto drukčiju sliku s obzirom na blizinu ležišta u Bosni. Isto tako je zanimljivo da se u novijoj literaturi (Nessel 2014) navodi da su te "pogače" ili engl. plano-convex ingots sadržavale isključivo bakar kao sirovinu.

\section{Izrada brončanih predmeta}

Kalupi su najčešći nalazi koji ukazuju na postojanje ljevačkog obrta u naseljima kulture polja sa žarama (sl. 1). U kasnome brončanom dobu upotrebljavali su se uglavnom dvodijelni kalupi koji su služili za serijsko lijevanje jednog tipa predmeta, a pojedini kalupi su služili za istovremeno lijevanje različitih tipova predmeta. Zahvaljujući razvijenoj ljevačkoj djelatnosti mogao se lijevati veći broj predmeta raznovrsnih oblika i funkcije.

Kalupi su se izrađivali od raznih sirovina, najčešće od kamena, koji je najotporniji na toplinske promjene, ali i od gline te rjeđe od metala. Oni od kamena bili su izrađivani od vrsta koje se mogu dobro obrađivati, a najčešće su to određene vrste pješčenjaka. Osim lijevanja, bronca se obrađivala i kovanjem, a tzv. hladno kovanje pozitivno utječe na tvrdoću materijala. Na prostoru Hrvatske kalupi su otkriveni u sklopu nalaza iz naselja i to osobito iz kasnoga brončanog doba (Kalnik-Igrišče, Mačkovac, Sv. Petar Ludbreški, Lovas, Kiringrad, Vinkovci, Podgajac Glogovica). U hrvatskoj Posavini istraživano je naselje Mačkovac-Crišnjevi (Karavanić et al. 2002) koje je dalo podatke o postojanju ljevačke djelatnosti. Na tom lokalitetu 1985. slučajno je pronađena ostava brončanih predmeta (Karavanić \& Mihaljević 2001). Tijekom samih istraživanja naselja otkriveno je jedno ognjište (Karavanić 2006: sl. 1-2) u blizini kojega je pronađen dio brončanog ingota (Karavanić 2006: sl. 5) težine oko 150 g. Osim njega pronađen je glineni nastavak za puhaljku mijeha ili sopalj.

SI. 1: Ulomci kalupa za lijevanje brončanih predmeta s lokaliteta Kalnik-Igrišče (fotografirao: Z. Homen, doradila: A. Kudelić).

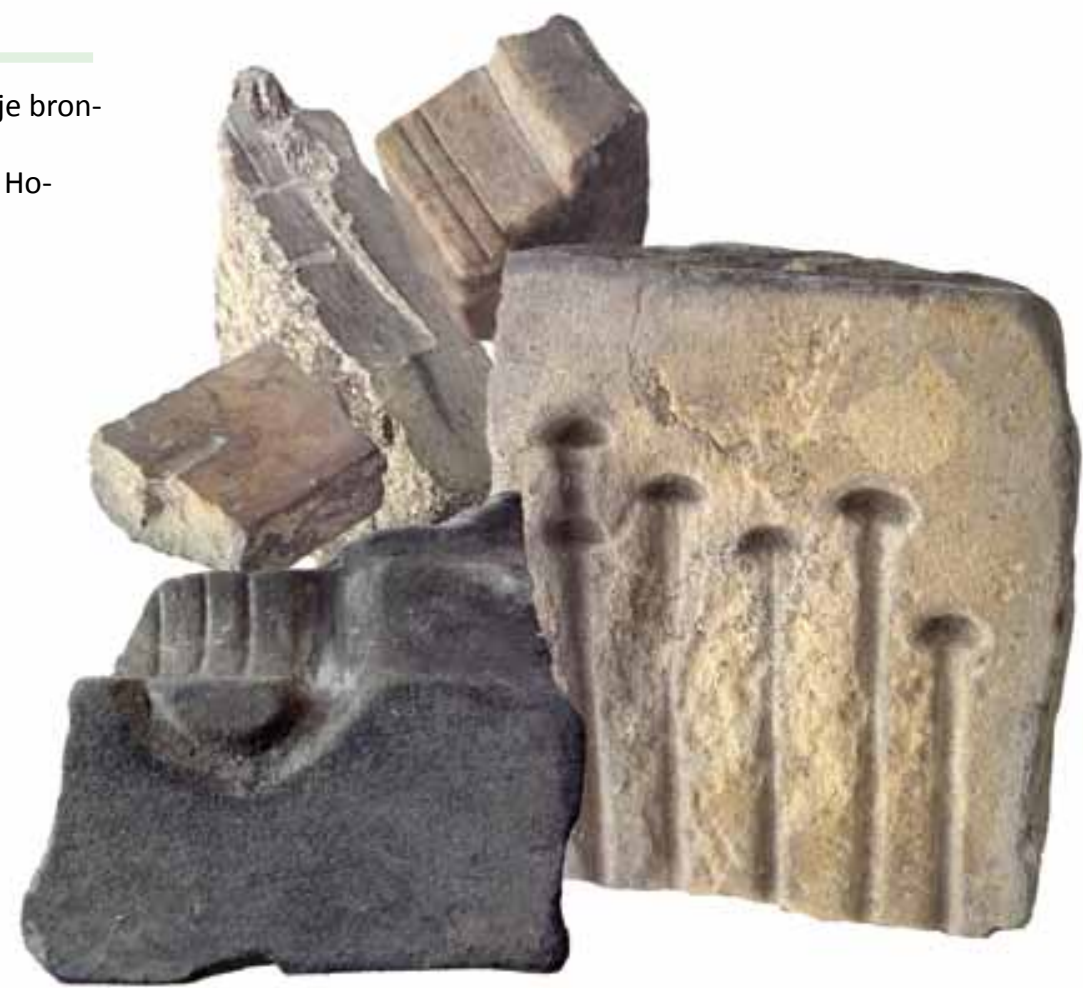


Ostave su skupine brončanih predmeta odjednom pohranjenih u zemlju. Sastojale su se od dva ili više predmeta koji su mogli biti cjeloviti, ali i fragmentirani. U kasnome brončanom dobu, osobito u 12. i 11. st. pr. Kr. najčešće su velike ostave tzv. mješovitog karaktera.

Područje Posavine osobito je značajno za ljevačku djelatnost kasnoga brončanog doba na teritoriju Hrvatske. Dokazi za to su brojne ostave brončanih predmeta (Vinski-Gasparini 1973; Miklik-Lozuk 2004; Karavanić 2009). Većina ostava pronađena je u nepoznatim okolnostima i nije produkt sustavnih istraživanja, ali se iz nekih opisa u inventarnim knjigama da zaključiti da su bile vezane uz naselja kasnoga brončanog doba.

S obzirom na užu geografsku pripadnost, u sjevernoj Hrvatskoj razlikuju se četiri skupine ostava, najbrojnija je brodska skupina, zatim zagorska, osječka te kordunska (Dizdar \& Ložnjak Dizdar 2011: 23). Za dio ostava s brodskog područja posljednje spoznaje pokazuju kako potječu iz naselja koja su bila istaknuta metalurška središta toga vremena te su zauzimala strateški istaknute položaje u onodobnoj komunikacijskoj mreži južne Panonije (Dizdar \& Ložnjak Dizdar 2011: 23). Statističkom analizom (Karavanić 2009) dobiveni su rezultati o broju ostava po kronološkim horizontima koje je odredila Vinski-Gasparini (1973), a iz čega je vidljivo da je ostavama najbrojnija kronološka faza II, koja odgovara stupnju Ha A prema srednjoeuropskoj kronologiji (1200. do 1050. pr. Kr.). Prema tome, stupnju II pripada 38 ostava brončanih predmeta, slijede faze IV i V koje imaju svaka po 8 ostava, a najmanji broj ostava, njih 6, pripada fazi III i fazi I (samo 1 ostava) (Vinski-Gasparini 1973; Karavanić 2009).

0 značenju ostava iscrpan pregled donosi W.a. Brunn (1968). Jedan dio autora ostavama je pripisao votivno značenje (Hansen 1994; Nebelsick 1997; Hänsel 1999), dok su njemački istraživači istaknuli i mogućnost njihova profanog značenja (Dizdar \& Ložnjak Dizdar 2011: 23). U novije vrijeme neki autori (Dietrich 2014) donose argumente koji idu u prilog tome da su i tzv. ostave ljevača mogle biti dio religioznog izričaja zajednica na čijem teritoriju su pohranjene.

Ostave su se uglavnom pripisivale majstorima ljevačima, a bile su skrivene zbog neke opasnosti. U većini ostava II faze kulture polja sa žarama nalaze se zajedno poluproizvodi, lijevani predmeti i sirovina u vidu plano-convex ingota ili lijevanih čekićastih ingota. Te se ostave u anglo- saksonskoj literaturi nazivaju još foundry hoards ili scrap hoards (Harding 2000; Bradley 2013), a u njemačkoj literaturi je uvriježen naziv Brucherzhorte. Lomljene predmete koji se pojavljuju u ostavama, zagovornici votivne teorije tumače kao dio žrtvenog obreda. Tako Nebelsick (1997) također u lomljenju brončanih predmeta ne vidi smišljeno i plansko djelovanje ljevača bronce, nego uništavanje predmeta u okvirima religioznih rituala.

Zagovornici profane teorije u njima vide slomljene predmete spremne za ponovnu proizvodnju (Dizdar \& Ložnjak Dizdar 2011: 24). A. Mozsolics (1985) je prikupila sve istaljene i spojene brončane predmete iz ostava Karpatske kotline i Mađarske i na jednostavan način dokazala da su bili upotrebljavani u sekundarne svrhe, tj. u ljevačkoj djelatnosti. Njezin je rad poslužio Clausingu kao osnova za analizu ostave Slavonski Brod (2003: 153) u kojoj izdvaja predmete takve vrste i tako povezuje ostavu s ostavama ljevača bronce. Zanimljivo je njegovo mišljenje da nema nikakvog razloga da sami ljevači i kovači nisu mogli zakopati svoja blaga u religiozne svrhe te navodi paralelu s nekim neindustrijskim društvima u kojima su upravo ljevači i kovači imali religioznu funkciju (Clausing 2003:149). Ovime se Clausing podudara s Hänselovim objašnjenjima (1997: 15). Hansen (1994: 387) navodi da su takvi polomljeni komadi tzv. Brucherzcharakter bili neupotrebljivi za votivne priloge, no također navodi da su mnogi paralelni votivni prilozi u Grčkoj bili dosta oštećeni i polomljeni. Hansen (1994: 387-388) također navodi da su u ostavama bili već upotrebljavani predmeti (najčešće su to oružje, oruđe i nakit i nošnja), ali i oni na kojima se vide još tragovi lijevanja. Hansen ponovo za ove posljednje smatra da nisu nužno trebali biti upotrebljavani za ponovno lijevanje nego su bili namijenjeni kao darovi bogovima, za što opet navodi primjere iz grčkoga svijeta (Hansen 1994: 388). 
Recikliranje predmeta pa tako i onih brončanih u brončanom dobu dio je „arheologije proizvodnje" koja obuhvaća različite stupnjeve u procesu recikliranja kao što su upotreba predmeta, lomljenje (engl. fracture) i recikliranje (Delfino 2014: 124). Predmeti koji su se reciklirali mogli su biti oni koji su bili dobro izrađeni, ali su istrošeni i izašli su iz upotrebe. Zatim su to predmeti koji su bili izliveni, ali nisu postigli željeni cilj u smislu oblikovanja. Drugu skupinu predmeta predstavljaju oni koji su bili oštećeni tijekom lijevanja i na njima se vide tragovi lijevanja. Posljednju skupinu čine oni koji koji nisu nikada niti bili namijenjeni za upotrebu i pripadaju otpadu (engl. waste).

Prema nekim autorima količina bakra koja se proizvodila u brončanom dobu još uvijek je u nerazmjeru s količinom arheoloških artefakata. Naime, još uvijek je otkriveno malo deponiranog brončanog materijala. Recikliranje brončanih predmeta vjerojatno se odvijalo već u ranom brončanom dobu i moguće je da se određeni predmet više puta reciklirao tijekom vremena tako da u kasnobrončanodobnim artefaktima imamo broncu iz ranoga brončanog doba. To otežava dobivanje kvalitetnih rezultata arheometrijskih analiza (Bradley 2013). Radi se o tome da kada je riječ o recikliranju onda je teško povezati pojedine predmete s izvorima, odnosno ležištima sirovina.

Što se tiče geografskog položaja i blizine ležišta sirovina prema Delfino (2014: 125) moguće je da su i zajednice koje su bile blizu ležišta bakra prakticirale recikliranje kako bi unaprijedile svoju proizvodnju brončanih predmeta. No vjerojatnije je (Bradley 1988: 252) da su zajednice imale određene poteškoće u održavanju kontinuirane opskrbe sirovinom, u ovom slučaju bakrom i kositrom.

Sam proces recikliranja bronce zahtijeva posebno znanje (engl. know-how) kako bi se dobila kvalitetna slitina ili legura. To se znanje prenosilo s generacije na generaciju.

Najbolje dokaze za moguće recikliranje predstavljaju nam ostave ljevača (engl.founder's hoards ili scrap hoards). Njih neki autori (Bradley 19882013) nazivaju još neritualnim ostavama ili tzv. dryland hoards. Ovo posljednje proizlazi iz perspektive okolnosti nalaza ostava u zapadnoj Europi, Engleskoj i Irskoj gdje nasuprot ostavama koje se nalaze u vodama i obično se pripisuju votivnim darovima, dolaze one koje su pronađene u zemlji. Iako se i one mogu naći uz različite vodotoke.

U ostavama ljevača nalaze se osim gotovih predmeta, i polomljeni i nedovršeni predmeti zajedno s ingotima koji mogu biti u obliku „pogača“ (engl. plano-convex ingoti) ili čekićastih ili lijevanih ingota. To su obično ostave koje su izuzetno velike i teške, a mogu imati stotine predmeta, neke i tisuću. Prema A. Harding (2000: 355) nije vjerojatno da su one bile transportirane na veće udaljenosti, nego su bile deponirane na jedno mjesto za buduću upotrebu. To mjesto je moglo biti označeno, a majstor ljevač bi dolaskom u selo mogao ponovo doći do onoga što je prethodno „sakrio“ ili bolje rečeno sačuvao za daljnji rad (Harding 2000: 355). Ovdje se nameće problem zašto je veliki broj tih ostava ostao sačuvan do današnjih dana i nikada nije bio upotrijebljen u procesu lijevanja. Autori nude različita objašnjenja, a jedno od njih je i ono Hardingovo (2000: 355) u kojemu on pretpostavlja da je veći broj ljevača „nestao“ prije nego su mogli ponovo „otkriti“ svoje predmete. I Bradley (2013) spominje sličan problem, ali to ostavlja otvorenim pitanjem iako je u ranijim radovima (Bradley 1988) postojanje ostava ljevača koje su bile namijenjene za recikliranje povezao s periodom kreativnosti ili krize, bilo estetske ili ekonomske. To je u suprotnosti s dominantnim mišljenjem kako je npr. faza II (12. st. pr. Kr.) vrijeme procvata metalurgije (Vinski-Gasparini 1973). Za zapadnu Europu Bradley (1988: 253) navodi da su u kasnom brončanom dobu korišteni izvori sirovina u atlantskoj Europi, a manje oni u srednjoj Europi koji su davali velike količine sirovine pa se zaključuje da je metalna industrija mogla imati određene poteškoće, osobito u nabavi sirovina. 
Također je zanimljivo da se u određenim razdobljima u kasnom brončanom dobu, pa tako i u periodu 12. st. pr. Kr. u Hrvatskoj i susjednim regijama, pojavljuju i u votivnim i u ljevačkim ostavama isti predmeti kao npr. primjerci oružja i nakita. Tako se, vidjet ćemo kasnije, u ostavama kulture polja sa žarama na području brodske i zagorske grupe pojavljuju ulomci mačeva i nakita. Cijeli mačevi nalaze se u vodama, npr. mač iz Jaruna u Zagrebu ili oni iz Šoderice kod Koprivnice u Podravini. Polaganje metala u votivne svrhe u zapadnoj Europi bilo je povezano s promjenama u gospodarstvu. Naime, budući da je većina metala završavala u votivnim ostavama, pojavila se velika potreba za metalom koji bi bio upotrijebljen za proizvodnju svakodnevnih predmeta (Bradley 1988: 255). Tako su se za recikliranje koristili predmeti koji su ostali u optjecaju. Potreba za predmetima za svakodnevnu upotrebu vjerojatno je povezana s usponom poljoprivrede u periodu brončanoga doba za koju je trebao cijeli niz oruđa kao što su srpovi, sjekire, dlijeta i dr.

U ostavama se mogu naći veća ili manje grumenja koja se sastoje od fragmenata bronci koji su zajedno istaljeni. Ponekad se radi o jednom ili dva komada, a ponekad o većoj količini. Mozsolics (1985: 24) navodi različito nazivlje za te nalaze pa tako prema R. Wyss to su „zusammengeschmolzene Altmetallklumpen“, a prema J.-P. Mohen to su „bronzes préfondus“. Engleski autori koriste termin „scrap metal“ (Bradley 2013). Također se u ostavama mogu naći zajedno savijeni i usitnjeni predmeti. Neki su bili dodatno spojeni udaranjem čekića ili nekog sličnog predmeta, odnosno na njima se vide tragovi kovanja ili udarca čekića (njem. gehammerte).

Što se tiče tzv. Altmetall u ostavama se najčešće nalaze savijeni komadi lima i to od sljedećih predmeta: vedra tipa Kurd, brončane posude, pojasevi i sl. (Mozsolics 1985: 25). Slične nalaze imaju i neke ostave međuriječja Drave, Save i Dunava (Vinski-Gasparini 1973) npr. ostava Brodski Varoš. Osim ovih većih komada lima kao rastaljene i savijene bronce pojavljuju se i drugi predmeti koji su mogli biti rezultat neuspjelog lijevanja pa su se morali ponovo taliti da bi se dobila kvalitetna brončana slitina i predmet od nje. Zanimljivo je da Mozsolics (1985: 26) povezuje te male grude istopljenog metala s obredom kremacije i grobovima u kojima su se nalazile uglavnom keramičke posude pa pretpostavlja da su metalni predmeti uzeti s lomače i stavljeni u ostave.

Pretežan dio ostava horizonta Kurd sadržavao je brojne ulomke bronce koji su mogli biti rezultat pogreške u procesu lijevanja i bili su potpuno neupotrebljivi kao npr. srpovi, pile i dr. Također je velik broj ulomaka mačeva i sjekira. Zanimljivo je da među oštećenim sjekirama postoje one koje su imale oštrice različite debljine što je bio rezultat lošeg postupka lijevanja (jezgra se pogrešno stavila u kalup) (Mozsolisc 1985: 26). Isto tako moglo se dogoditi da se slitina brzo hladila pa nije moglo biti dovoljno metala za lijevanje. Kod lijevanja u dvodijelnim kalupima moglo se dogoditi da zbog pritiska plinova pri lijevanju dođe do oštećenja kalupa ili da se jezgrenici kalupa nisu dobro postavili, tj. nisu se dobro podudarali pa se to odrazilo na lijevanje predmeta. Također je taj istopljeni ili oštećeni metal bio važan kao sirovina za područja koja su bila dosta udaljena od ležišta sirovina, međutim to je sigurno u suprotnosti s ostavama Transilvanije, a vjerojatno i s ostavama u brodskom području u Hrvatskoj za koje se pretpostavlja postojanje sirovina u Bosni (Durman 1997).

Oštećeni predmeti nisu uvijek bili nanovo taljeni nego su se mogli ponovo obraditi i tako proizvesti nov, upotrebljiv predmet. Posebnu skupinu čine predmeti od žice koji su nekada bili dijelovi nakita, a sada su savijeni i vjerojatno su isto bili namijenjeni za ponovno taljenje da bi se izradio neki drugi predmet. Veliki broj predmeta pripadao bi i tzv. poluproizvodima, a to su predmeti koji nakon lijevanja nisu bili dodatno obrađeni kako bi bili spremni za upotrebu pa se na njima još vide tragovi lijevanja tzv. Gusszapfen i Gussnahte (Mozsolics 1985: 28). 
Clausing (2003: 153) u svojoj objavi ostave Slavonski Brod, oslanjajući se na rad Mozsolics (1985), navodi da se u istoimenoj ostavi nalazi ulomak srpa, ulomak spirale, jedan grumen ili grumen koji je imao brončano sječivo na gornjoj strani, a na donjoj strani otisak koncentričnog kruga i konačno na fragmentu jednog sječiva sjekire sa zaliscima ležao je ulomak dlijeta. Clausing (2003: sl. 43, 44) donosi ulomke brončanih „kolača“ ili „pogača“ zajedno s grudama istaljene bronce i s Gusszapfen. Clausing (2003: 152) se djelomično ograđuje od mišljenja A. Mozsolics (1985) ali ne donosi jasne argumente za to. On se također referira na neke druge nalaze ukazujući na moguće pogrešno interpretiranje korozije kao proizvoda ponovnog procesa taljenja metala.

Međutim, u većini literature prevladava mišljenje da su ti ulomci predmeta, oštećeni predmeti i istaljene bronce činile inventar ostava ljevača. Na području Rumunjske nalaze se također velike ostave mješovitog karaktera kao što je Uioara de Sus koja teži 1133 kg, a među nalazima od 3513 predmeta nalazi se 2299 brončanih „kolača“ i lomljene bronce s težinom od $1000 \mathrm{~kg}$ (Mozsolics 1985: 23, bilješka 19). Kao primjer ljevačke ostave može se navesti ona iz Dragomelja u Sloveniji (Turk 1997).

Od brojnih ostava s brodskog područja izdvajamo ostavu iz Brodskog Varoša. Za nju (VinskiGasparini 1973: 90) se navodi da je imala više od 1000 komada bronce, koji su 90\% oštećeni ili sačuvani samo u ulomcima, a uz to je imala dosta amorfnog grumenja (sl. 2) i sirovine u obliku «pogača» (engl. plano-convex ingots). Pretpostavka je da se radi možda o više ostava ljevača bronce koje su bile sastavljene naknadno.
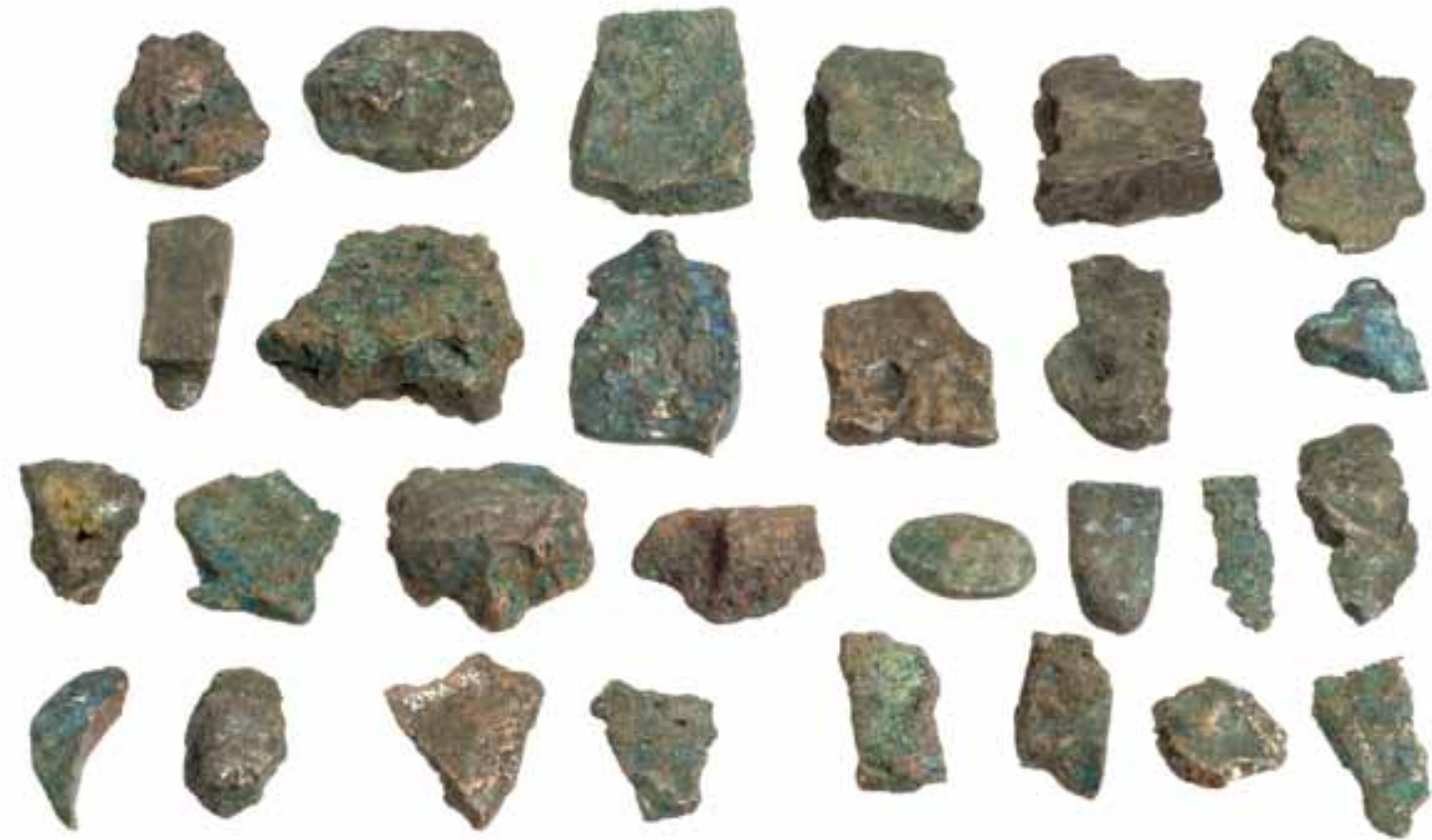

SI. 2: Amorfna grumenja bronce iz ostave Brodski Varoš (fotografirao: I. Krajcar, Arheološki muzej u Zagrebu). 


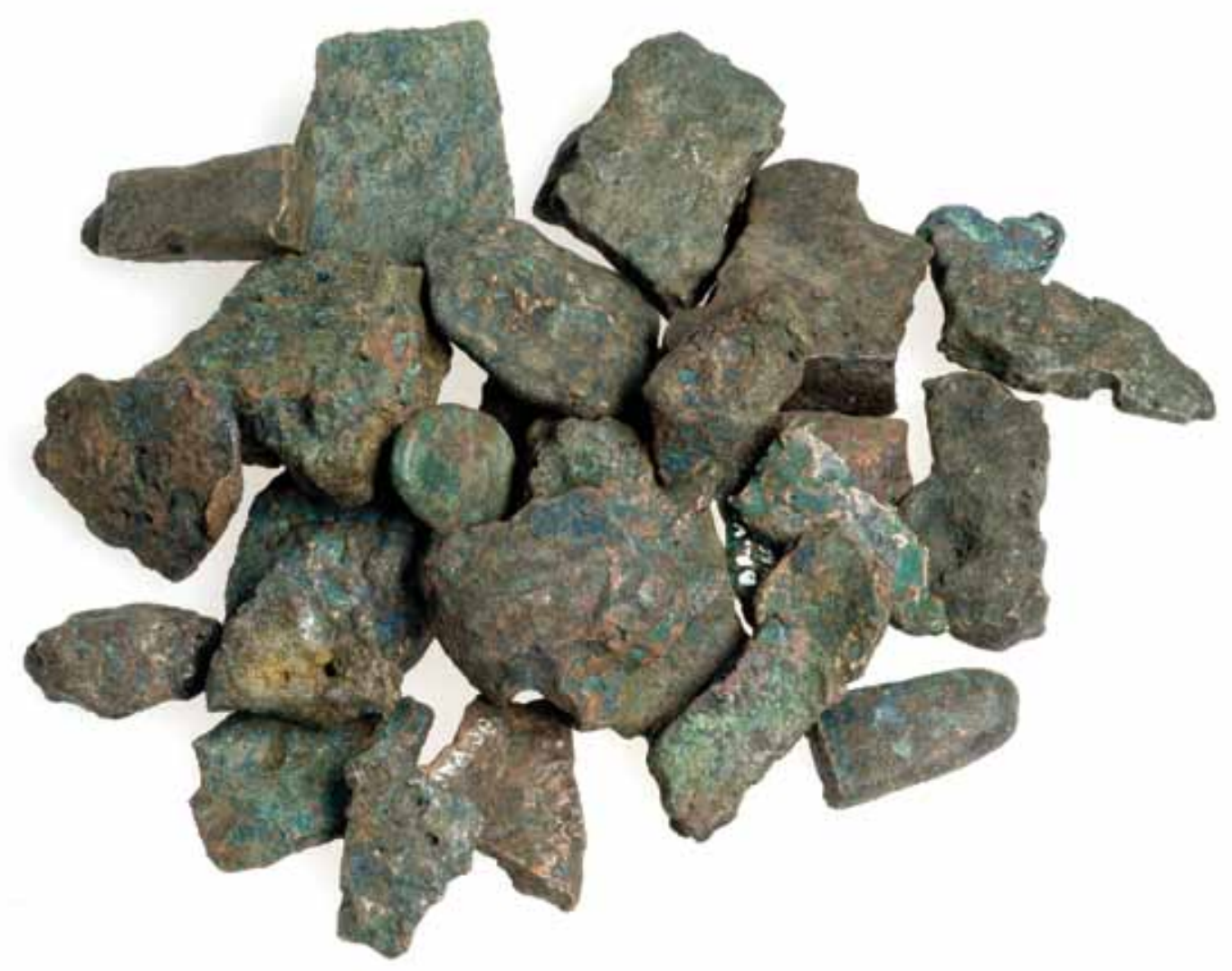

Među inventarom ostave koji se čuva u Arheološkom muzeju u Zagrebu nalaze se ulomci ingota (sl. 3), zatim dijelovi brončanih predmeta koji su bili naknadno istaljeni, vjerojatno zato jer nisu više zbog istrošenosti bili u upotrebi ili nisu bili adekvatno izliveni (sl. 4). Zanimljivi su i ulomci predmeta od brončane žice (sl. 5) koji su vjerojatno bili dijelovi nakita i nošnje. Uvidom u inventar ostave došli smo do zaključka da jedan dio predmeta pripada ostacima od lijevanja bronce u kalupima (njem. Gusszapfen) (sl. 6).

SI. 4: Ulomak naknadno istaljenog brončanog predmeta iz ostave Brodski Varoš

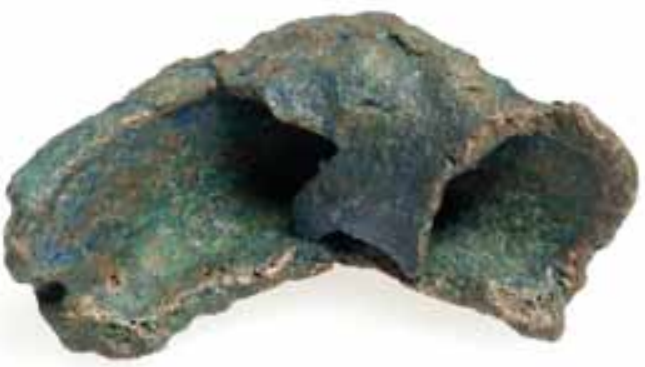
(fotografirao: I. Krajcar, Arheološki muzej u Zagrebu). 
SI. 5: Ulomci predmeta od spiralne žice iz ostave Brodski Varoš (fotografirao: I. Krajcar, Arheološki muzej u Zagrebu).

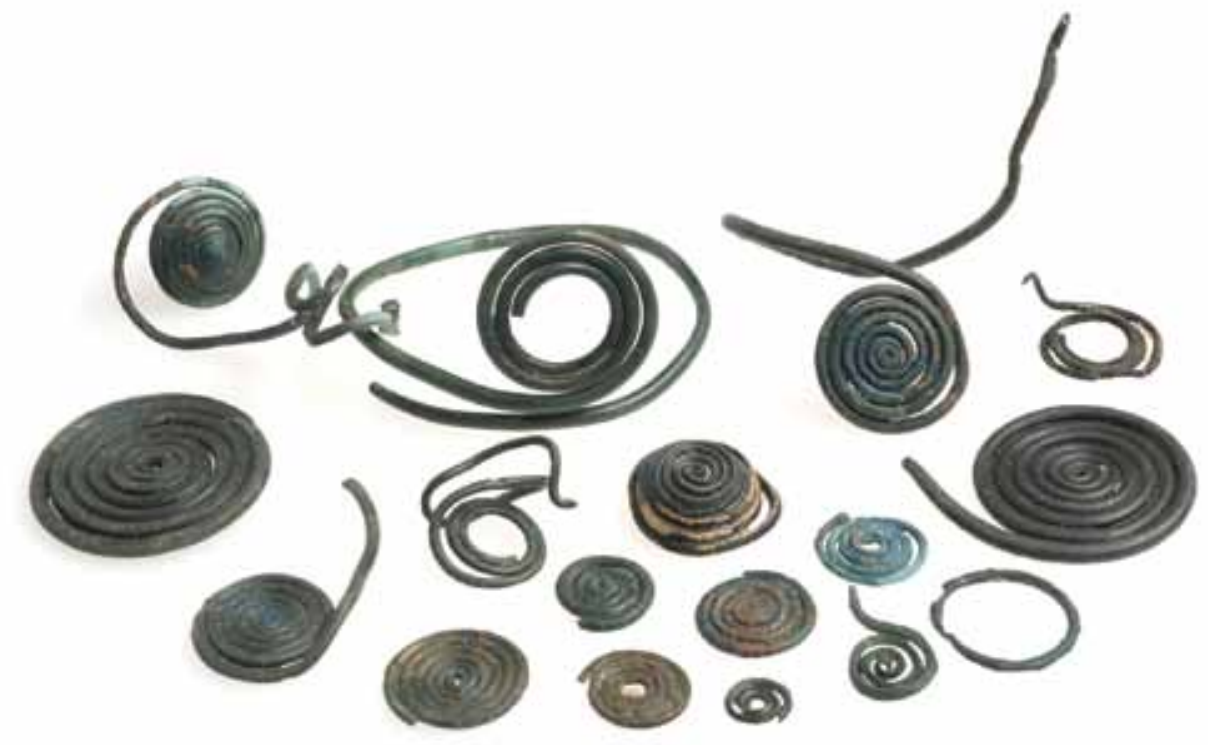

O njima i njihovoj funkciji piše Nessel (2012). Upravo su ti ostaci bronce od lijevanja u kalupima kao i nalaz punce (sl. 7) dokaz da je ova velika skupina brončanih predmeta vrlo vjerojatno bila korištena u jednoj fazi proizvodnje metalnih predmeta kojoj je prethodilo i recikliranje.

Neki autori u novije vrijeme ne smatraju da su tzv. plano-convex ingoti ili popularno zvane „pogače" korištene u recikliranju jer su analize pokazale da se ovdje radi o ingotima od bakra, a ne od slitine bakra i kositra (Nessel 2014).
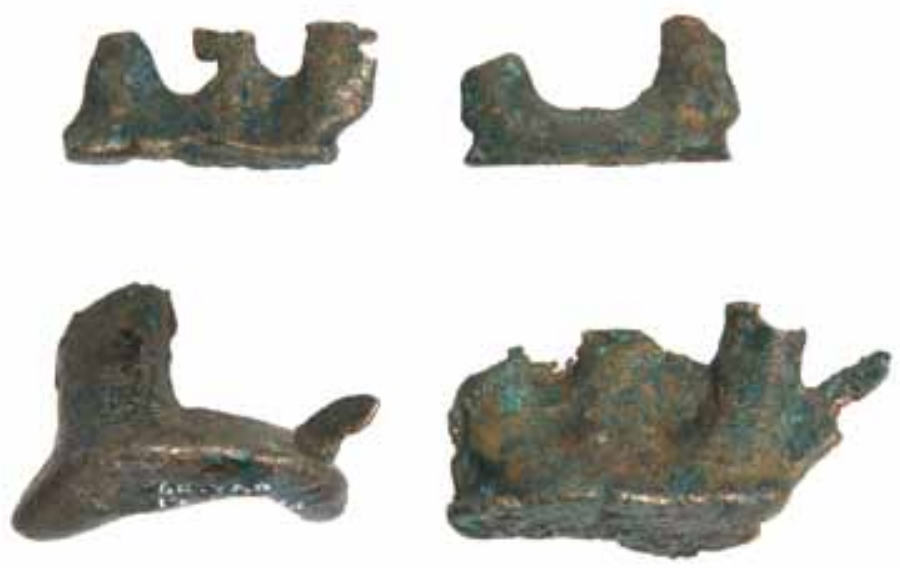

SI. 6: Ostaci od lijevanja bronce u kalupima (njem. Gusszapfen) iz ostave Brodski Varoš (fotografirao: I. Krajcar, Arheološki muzej u Zagrebu). 
SI. 7: Nalaz punce iz ostave Brodski Varoš (fotografirao: I. Krajcar, Arheološki muzej u Zagrebu).

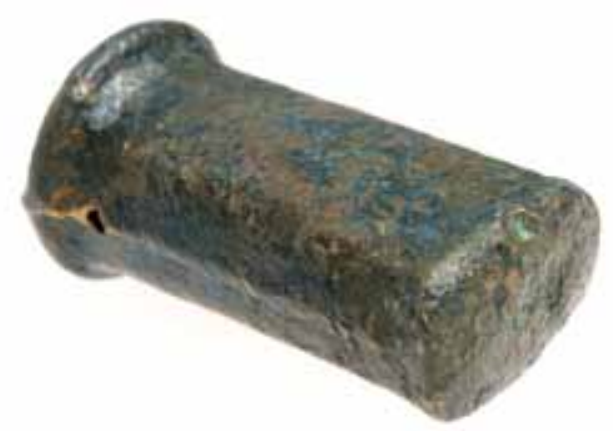

Kako analize iz hrvatskih ostava još nisu objavljene, osim Miljane (Smodič 1956) i Pustakovec (Riederer 1999), možemo samo pretpostaviti da se u našem slučaju radi o sirovini bronce koja se dolaskom u radionička središta dalje reciklirala. U svakom slučaju ova ostava svjedoči o bogatoj i raznovrsnoj proizvodnji metala u hrvatskom dijelu Posavine. Ona je i dobar pokazatelj procesa recikliranja metala u kasnom brončanom dobu kao posebnom segmentu proizvodnje brončanih predmeta u lokalnim zajednicama i naseljima kulture polja sa žarama (lokalna kulturna grupa Barice-Gređani). Većina brodskih ostava vjerojatno je nađena u naseljima grupe Barice-Gređani (npr. Mačkovac) (Karavanić \& Mihaljević 2001), a da je na tom području sigurno bila razvijena ljevačka djelatnost govori nam u prilog i noviji nalaz kamenih kalupa iz naselja Podgajac-Glogovica (Kulenović 2016).

Recikliranje brončanih predmeta u brončanom dobu vrlo je dobar primjer recikliranja koje je zahtjevalo ne samo spoznaju o selekciji pojedinih predmeta nego i posebnu vještinu u okviru procesa proizvodnje brončanih predmeta. Iako jedan dio novije literature i autora osporava recikliranje, mišljenja smo da su tako velike količine polomljenih, nedovršenih ili oštećenih brončanih predmeta (sačuvani u ostavama) sigurno služile kao sredstvo recikliranja u svrhu dobivanja što kvalitetnijih utilitarnih i prestižnih brončanih predmeta. Kao i većina ostava iz kasnog brončanog doba u Europi, tako su i ostave kulture polja sa žarama u sjevernoj Hrvatskoj (npr. Brodski Varoš) dale valjane dokaze o praksi recikliranja i proizvodnji brončanih predmeta. Njihova povezanost s istovremenim naseljima govori u prilog tome da se cjelokupni postupak proizvodnje, pa tako i recikliranje, mogao odvijati unutar svakog pojedinog naselja. Stoga je proces recikliranja potrebno promatrati kao dio svakodnevne djelatnosti unutar pojedine brončanodobne zajednice.

\section{Literatura}

Bradley, R. 1988. Hoarding. Recycling and the Consumption of Prehistoric Metalwork: Technological Change in Western Europe. World Archaeology Vol. 20. 249-260.

Bradley, R. 2013. Hoards and the Deposition of Metalwork. U: Oxford Handbook of European Bronze Age (ur. A. Harding \& H. Fokkens). Oxford University Press. Oxford. 121-139.

Brunn, W.A.v. 1968. Mitteldeutsche Hortfunde der jüngeren Bronzezeit, Römisch-Germanische Forschungen 29. De Gruyter. Berlin.

Clausing, C. 2004. Ein urnenfelderzeitlicher Hortfund von Slavonski Brod, Kroatien. Jahrbuch des Römisch-Germanischen Zentralmuseums Mainz 50/1. Mainz. 47-205. 
Craddock, P. T. 1995. Early Metal Mining and Production. Edinburgh: University Press. Edinburg. Delfino, D. 2014. Bronze recycling during the Bronze Age: some consideration about two metallurgical regions. Antrope 1. 2014. Centro de Pré-História. 121-142.

Dietrich, 0. 2014. Learning from „scrap“ about Late Bronze Age hoarding practice. A biographical approach to individual acts of dedication in large metal hoards. European Journal of Archaeology 17. 468-486.

Dizdar, M. \& Ložnjak Dizdar, D. (ur.) 2014. The Beginning od the Late bronze Age between the Eastern Alps and the Danube. Proceedings of the International conference in Osijek. October 20-2. 2011. Zagreb. Institut za arheologiju.

Durman, A. 1997. Tin in southeastern Europe? Opuscula Archaeologica 21. Zagreb. 7-14.

Durman, A. 2004. Katalog izložbe Hromi bog Hefest. Gradski muzej Vukovar. Vukovar.

Fischl Pusztaine, K., Kiss, V., Kulcsar, G., Szevereny, V. 2015. Old and new narratives for Hungary around $2200 \mathrm{BC}$. U: 220 BC - A climatic breakdown as a cause for the collapse of the Old World. Tagung der Landesmuseums für Vorgeschichte Halle. Band 12/II. Halle (Saale). Landesmuseum für Vorgeschichte. 501-523.

Furmánek, V. \& Vladar, J. 2002. Der Stand der Metallanalysentätigkeit in der Slowakei. U: Anfänge der Metallurgie in der Alten Welt ( ur. M. Bartelheim, E. Pernicka \& R. Krause). Forschungen zur Archäometrie und Altertumswissenschaft 1. Rahden/westf. Verlag Marie Leidorf. 255-263.

Glogović, D. 2000. Novoobjavljena ostava Pustakovec i ostale prapovijesne ostave iz sjeverozapadne Hrvatske. Prilozi Instituta za arheologiju 17. Zagreb. 103-111.

Glogović, D. \& Miko, S. 2000. Sadržaj elemenata u tragovima i olovnih izotopa u dva bakrena grumena iz ostave u Dežmanovu prolazu u Zagrebu. Prilozi Instituta za arheologiju 17. Zagreb, 89-93.

Hänsel, B. 1997. Gaben an die Götter - Schätze der Bronzezeit Europas - eine Einführung. U: Gaben an die Götter. Schätze der Bronzezeit Europas (ur. A. and B. Hänsel). Museum für Vor- und Frühgeschichte Bestandskatalog. Berlin. 11-22.

Hänsel, A. 1999. Ein älterurnenfelderzeitliches Depot aus Pustakovec, Kot. Čakovec, Kroatien. Acta Praehistorica Archaeologica 31. Berlin. 76-92.

Hansen, S. 1994. Studien zu den Metalldeponierungen während der älteren Urnenfelderzeit zwischen Rhonetal und Karpatenbecken. Universitätforschungen für prähistorische archäologie 21. Habelt. Bonn.

Harding, A. F 1998. Reformation in Barbarian Europe. 1300-600 BC. U: Prehistoric Europe an illustrated History. (ur. B. Cunliffe). Oxford University Press. Oxford, New York. 304-335.

Harding, A. F. 2000. European Societies in the Bronze Age. Cambridge University Press. Cambridge.

Karavanić, S., Mihaljević, M. \& Kalafatić H., 2002. Naselje Mačkovac-Crišnjevi kao prilog poznavanju početaka kulture polja sa žarama u slavonskoj Posavini. Prilozi Instituta za arheologiju 19. Zagreb. 47-62.

Karavanić, S. 2006. Prerada i proizvodnja metala u naselju Mačkovac-Crišnjevi (Nova Gradiška). Prilozi Instituta za aeheologiju 23. Zagreb. 29-52.

Karavanić, S. 2009. The Urnfield Culture in continental Croatia. British Archaeological Reports International Series 2036. Archaeopress. Oxford.

Karavanić, S. \& Mihaljević, M. 2001. Ostava iz Mačkovca. Vjesnik Arheološkog muzeja u Zagrebu XXXIV. Zagreb. 7-36. 
Krause, R. 2003. Studien zur kupfer- und frühbronzezeitlichen Metallurgie zwischen Karpatenbecken und Ostsee. Vorgeschichtliche Forschungen 24. Rahden/Westfal. Verlag Marie Leidorf. Kristiansen, K. 1998. Europe before History. Cambridge University Press. Cambridge.

Kulenović, I. 2016. Kasnobrončanodobno naselje Podgajac-Glogovica kod Slavonskog Broda. Prilozi Instituta za arheologiju 33. Zagreb 53-87.

McGeehan-Liritzis, V. \& Taylor, J. W. 1987. Yugoslavian Tin deposits and Early Bronze Age industries of the Aegean region. Oxford Journal of Archaeology 3. Oxford. 287-300.

Miklik-Lozuk, L. 2004. Ostava Poljanci IV još jedna kasnobrončanodobna ostava s pozicije Donje Polje u selu Poljanci. Vjesnik Muzeja brodskog Posavlja 9. Slavonski Brod. 29-51.

Minichreiter, K. 1982-1983. Pregled istraživanja nekropola grupe „Gređani“ u Slavoniji. Anali Zavoda za znanstveni rad u Osijeku 2. Osijek. 7-122.

Mozsolics, A. 1985. Ein Beitrag zum Metallhandwerk der ungarischen Bronzezeit. Bericht der Römisch-Germanischen Komission 65 (1984). Frankfurt a/Main. Berlin. 19-72.

Nebelsick, L. D. 1997. Auf Biegen und Brechen. Ekstatische Elemente bronzezeitlicher Materialopfer - Ein Deutungsversuch. U: Gaben an die Götter. Schätze der Bronzezeit Europas (ur. A. and B. Hänsel). Museum für Vor- und Frühgeschichte Bestandskatalog. Berlin. 35-41.

Nessel, B. 2012. Alltägliches Abfallprodukt oder Marker bevorzugter Gusstechnik? Zu bronzenen Gusszapfen zwischen Karpaten und Ostsee. Universität forschungen zur prähistorichen Archäologie 21. Dr. Rudolph Habelt Verlag. Bonn. 145-159.

Nessel, B. 2014. Bronze Age Portioning of raw Metal-Concepts, Patterns and Meaning of Casting Cakes. Apulum 51. Alba Iulia. 401-425.

Pernicka, E. Begemann, F., Schmitt-Strecker, S., Wagner, G. A. 1993. Eneolithic and Early Bronze Age copper artefacts from the Balkans and their relations to Serbian copper ores. Prähistorische Zeitschrift 68/1. Berlin. 1-54.

Riederer, J. 1999. Die Metallanalyse der Gußkuchen aus dem urnenfelderzeitlichen Depot von Pustakovec, Kroatien. Acta Praehistorica Archaeologica 31. Berlin. 93-95.

Schalk, E. 2002. Forschungen zu den frühen Metallzeiten im nördlichen Karpatenraum. U: Anfänge der Metallurgie in der Alten (ur. M. Bartelheim, E. Pernicka \& R. Krause). Forschungen zur Archäometrie und Altertumswissenschaft 1. Rahden/westf. Verlag Marie Leidorf. 265-275.

Smodić, A. 1956. Bronasti depo iz Miljane. Arheološki vestnik VII. Ljubljana. 43-50.

Trampuž-Orel, N. 1999. Archaeometallurgic Investigations in Slovenia. U: Depojske in posamezne kovinske najdbe bakrene in bronaste dobe na Slovenskem II (ur. B. Teržan). Katalogi in monografije 29-30. Narodni muzej. Ljubljana. 165-242.

Trampuž-Orel, N. 1996. Spektrometrične raziskave depojskih najdb pozne bronaste dobe. U: Depojske in posamezne kovinske najdbe bakrene in bronaste dobe na Slovenskem (ur. B. Teržan). Katalogi in monografije 29-30. Narodni muzej. Ljubljana. 165-242.

Turk, P. 1997. Das Depot eines Bronzegiessers aus Slowenien - Opfer oder Materiallager? U: Gaben an die Götter. Schätze der Bronzezeit Europas (ur. A. and B. Hänsel). Museum für Vor- und Frühgeschichte, Bestandskatalog. Berlin. 49-52.

Tylecote, R. F. 1976. A History of Metallurgy. Metal Society. London.

Vinski-Gasparini, K. 1973. Kultura polja sa žarama u sjevernoj Hrvatskoj. Radovi Filozofskog fakulteta. Zadar. 